\title{
CHURCH TEEN CLUBS, FEMINIZED ORGANIZATIONS? TUXIS BOYS, TRAIL RANGERS, AND CANADIAN GIRLS IN TRAINING, 1919-1939*
}

\section{Lucille Marr}

By the beginning of the twentieth century, the Methodists and Presbyterians faced a crisis. Many youth, especially boys, were leaving the churches. In the hopes of encouraging their young people to stay involved, officials from these denominations adopted a new educational programme for youth. For boys, they used the YMCA's Canadian Standard Efficiency Training (CSET) and for girls, the YWCA's Canadian Girls in Training (CGIT). Religious educators found that the CGIT worked well as a church programme, but they were disappointed with the CSET. Indeed, expectations that the Trail Rangers and Tuxis boys' clubs, which used the YMCA's CSET, would keep young men active in the churches remained unfulfilled. Clergymen felt discouraged as they observed United Church boys joining non-church groups such as Scouts. At the same time, they looked with envy at the success of the CGIT.

Take for instance Rev. Normal Coll's 1929 report to the United Church Board of Religious Education. At that time, Coll was religious education field secretary for the Montreal and Ottawa conference of the United Church. From his perspective as overseer of religious education in that conference, he was pleased with the progress made by the female leaders in charge of the girls' clubs. In his view, the CGIT's success was largely due to the work of Mary Allison and Bona Mills, the national officials hired to oversee United Church girls' organizations.

Coll was uneasy, on the other hand, with what he perceived to be the weak leadership of the boys' clubs. In 1929, Frank Langford, Associate General Secretary of the United Church Board of Religious Education, was in charge of boys' work along with his other administrative duties, as he had been since church union in 1925. It would be seven long years before the United Church would recognize that Langford's administrative duties precluded his programme work and find funding to hire a national boys' secretary. Coll, worried about this gap in national leadership, knew that with his varied responsibilities as field secretary, he had neither the time nor the energy to devote to boys' work in Ottawa and Montreal. In his mind, the Montreal YMCA and the Scouts were examples of organizations which had taken seriously their opportunity to train boys. Coll was certain that the boys' workers hired by the YMCA and the Scouts explained why United Church boys and their leaders found these groups so appealing. Indeed

(c) HSEIRHÉ 3,2(1991): $249-267$ 
Boy Scouts claimed the loyalty of nearly 700 United Church boys, almost twice the number involved with the Trail Rangers and Tuxis programmes. In addition, over $50 \%$ of the 2,300 boys enrolled in Montreal's YMCA programmes were United Church. ${ }^{1}$

Coll's observations illustrate the relative success of the girls' and boys' clubs in the Methodist, Presbyterian, and United Churches in the interwar decades. Clergymen watched the CGIT mature as a church organization, all the while asking themselves why their boys' programme failed to grow in similar proportions. It seems ironic that the men who held authority in the institution had difficulty meeting their goal of keeping boys in the church. In contrast, in spite of their lack of formal power, women nurtured and mentored a future generation of female church workers.

Male religious educators like Coll were convinced that national leadership was at the root of the problem. While the Methodist and Presbyterian Sunday Schools Boards had hired professional women specifically to promote CGIT as early as $1918,{ }^{2}$ it was left to the already overworked administrators to promote the CSET for boys. Not until 1936 did the United Church hire its first boys' work secretary. From the historical retrospective, however, the leadership only symbolized a much broader issue which had been at work in the liberal Protestant denominations since the early nineteenth century. As Ann Douglas has ably demonstrated in her provocative study, The Feminization of American Culture, these churches had become "feminized." In large measure they were feminine institutions run by a handful of male ministers. The difficulty of interesting laymen and their sons in the church had social and cultural causes beyond the clergy's control. ${ }^{3}$

The teen clubs offer an ideal context from which to analyse this phenomenon, for while the high proportion of girls was typical also of children's clubs and the societies for post-teens, the CGIT and the Trail Rangers and Tuxis boys stand alone as parallel male and female church organizations. ${ }^{4}$ Until now, most histories of the CSET and the CGIT have been written in a secular context, but by 1920 these programmes were adopted by the churches and the CGIT fit better into the church structure and theology than did the CSET. ${ }^{5}$ In this paper I propose to analyse the agenda of the CGIT and the CSET, showing that the female approach was more compatible with church life than was male technique. The success of the girls' clubs is striking. The CGrT was slower in getting started, but soon outnumbered the boys' clubs and by 1939 boasted 33\% more groups.

\section{The Canadian Standard Efficiency Tests}

Clerical reformers, along with other reformers, were concerned with the "young boy problem," for great numbers of boys had been leaving the Sunday schools since the late nineteenth century. ${ }^{7}$ Not only were most young people's 
societies predominantly made up of girls, but many of the leaders were women. Thus by 1900 , work with middle-class boys had become central to the YMCA's task of saving young men, and local YMCAs began to employ salaried boys' workers. ${ }^{8}$ By 1920, fifty-four Canadian YMCAs were doing boys' work, fortytwo with secretaries hired specifically for the task. ${ }^{9}$

Scholars have suggested that the exodus of boys from the churches may be explained by the "feminization" of religion that had occurred in mainstream Protestant churches by that time. These studies argue that with industrialization, the masculine sphere had moved to the world of business and the nurture of children and things of the spiritual realm were left to the women and clergy in the domestic environment of their homes and the churches. ${ }^{10}$ This "feminization" is best illustrated by a theological shift that had taken place in these churches by the late nineteenth century. By mid-century, church leaders had begun to recognize that children reared in the church were their most likely source of future members. ${ }^{11}$ Thus a new means of evangelism evolved. The old idea that children were depraved human beings and that by adulthood a crisis conversion experience was necessary before becoming a church member, began to give way to the concept of Christian nurture. Respected Methodist and Presbyterian ministers including Henry Bland, Egerton Ryerson, and John Thompson advocated views which had already been made popular in the United States by Horace Bushnell. The new theology held that children were loved by God right from birth and it was the responsibility of the churches to educate them and to nurture them gradually into church fellowship. ${ }^{12}$

The new focus on children was strongly associated with maternal nurture. Women came to be preferred as Sunday-school teachers both in their obvious role as child-rearers and also for their moral influence on society. It is doubtful whether the advocates of Christian nurture recognized the "pedagogical control" that women would come to exert over the young. As Ann Douglas put it, "children who had once been required to sit, no matter how restlessly, through the adult service, might now receive their earliest religious instruction from a woman rather than from a minister." ${ }^{3}$ Ultimately, women's role in Christian nurure would mean that most girls would follow in their female teachers' footsteps, while boys would be more likely to look outside of the domestic realm of their homes and the churches for role models. ${ }^{14}$

Scholars have suggested that the phenomena of absentee fathers, and of mothers "teaching boys to be men," created feelings of inadequacy in adolescent boys which resulted in the need to prove their masculinity. ${ }^{15}$ In their quest for manliness, boys became preoccupied with an endless need to prove their strength and independence. This led to an obsession with the physical and a concentration on personal success, rather than the Christian emphasis on community service and cultivation of the inner man which had been characteristic of the eighteenth and early nineteenth centuries. ${ }^{16}$ In David Mcleod's words, by the twentieth century "manliness" had changed meaning, "coming to signify less the opposite of childishness than the opposite of femininity," and "an enduring fear of 
anything effeminate accounted for much of the...obsessively muscular Christianity" touted for young men. ${ }^{17}$

Reformers and churchmen were concerned for the future of twentieth-century manhood. In 1914, the Canadian Methodists and Presbyterians, who had been unable to achieve their objectives of creating denominational boys' programmes, had begun to cooperate in a formal way with several other denominations and the YMCA. Although some ministers worried about competition with the churches and "questioned the...quality of the religious work" of the YMCA, others recognized it as "the handmaid of the church." church and YMCA leaders had been enthusiastic about Boy Scouts, but the groups soon parted ways because Scout leaders were not primarily churchoriented. Furthermore, Scouting failed to recruit the older boys in whom the churches and the YMCA were interested. ${ }^{19}$ Thus Presbyterian and Methodist religious educators, namely John Robertson, Charles Myers, andFrank Langford, along with Anglican, Baptist, and Salvation Army church leaders joined with the YMCA to establish the Canadian Advisory Committee on Cooperation for Boys' Work to promote the YMCA's new plan for boys. ${ }^{20}$

The YMCA's new programme was the CSET which had been published in 1912. Taylor Statten, who had become national boys' work secretary of the YMCA that year, had worked with a planning committee of YMCA laymen and such Sunday-school leaders as Charles Myers to create the CSET. The programme followed the YMCA's old four-fold formula, clustering a series of tests and awards under the four categories of living defined by the YMCA as intellectual, spiritual, physical, and social. Before 1920, separate manuals were ready for Trail Rangers (ages 12-14) and Tuxis boys (15-17). ${ }^{21}$

The YMCA's ownership of the CSET was short-lived, however. A variety of circumstances resulted in the CSET being tumed over to the churches by 1921 . Not only had the war left the YMCA in severe financial straits, but the churches were interested mainly in working with Sunday-school youth and the YMCA was unprepared to limit its work to young men with specific church affiliations. ${ }^{22}$ By this time, there was a new ecumenical structure in place whose primary purpose was to promote religious education in the churches. The Religious Education Council of Canada (RECC), as it was called, had been formed by the Methodists and Presbyterians, along with several other groups, in 1919. The National Advisory Committee for Cooperation in Boys' Work became an arm of the RECC, separate from the YMCA, which was also represented on the new council. ${ }^{23}$ By this time the CSET boasted 1155 organized groups with some thirteen thousand boys as members and clergymen anticipated that the programme would continue to grow under their leadership. ${ }^{24}$ Throughout the twenties and thirties religious educators, particularly those from the uniting churches, promoted boys' work and encouraged those local congregations who had not yet tried the new programme, to give it a chance.

Though the programme, as Statten and his committee had planned it, focused on the intellectual, physical, social, and religious aspects of boy life, the CSET 
emphasized the "muscular" aspects of Christianity, physical prowess and intellectual maturity, over the spiritual and the social. To be "strong socially" had little to do with bettering the community; it meant that a boy would make his "leisure time profitable" and acquire "a strength of personality" which would enable him "to achieve that which he little dreamed lay within his power." Likewise, to develop religiously had little to do with cultivation of the inner spirit; it focused on the organization, urging boys to centre their lives around the Tuxis Square which met twice weekly, on Sunday and once during the week. ${ }^{25}$

Probably the most innovative aspect of the CSET, as Statten envisioned it, was the Boys' Parliaments. South of the border, this aspect of the Canadian programme won the praise of Professor J. M. Artman, the Director of Religious Education and Vocational Training at the University of Chicago, which was the heart of North America's religious education movement. Describing the CSET as one of "the most significant developments in religious educational procedure now in existence," Artman further depicted the Boys' Parliaments as "the high point of a Religious Education movement worth watching." 26

Provincial Boys' Parliaments were held annually across the Dominion in every provincial Parliament building except Quebec's. In each province, boys who were declared by their ministers to be church-members and "not addicted to the use of intoxicants, narcotics, or tobacco," were elected from several districts. These boys then campaigned to win election to the Provincial Boys' Parliaments and they were also eligible to run for National Parliament. ${ }^{27}$ The boys travelled from church school to church school, often speaking to entire church groups, presenting their various platforms of activities for Canadian youth. Sometimes they further strengthened their case by writing articles for their local newspapers, showing why they should be elected. The elections culminated in three days in Parliament. After the pomp and ceremony of formal opening procedures, the boys followed parliamentary rules discussing, debating, amending, passing, and defeating bills aimed at further developing the boys' movement.

From his perspective as a religious educator, Artman found it exciting to observe Manitoba boys spending several days during their 1925 Christmas vacation grappling with moral and religious issues in Parliamentary sessions:

It is spiritually exhilarating to share with boys seeking to eliminate professionalism in athletics and pledging themselves to eradicate such evils in their districts by themselves refusing, sometimes at great financial sacrifice, to have any part in such practice, and by campaigning throughout their districts for all youth to do the same. The movies, belittling amusements, cheap reading, lack of church attendance, stronger programmemes for Father and Son week...all come in for debate. $^{28}$ 
Although the boys were being trained in moral values, parliamentary procedure prepared the men of the future for positions in the world of politics and business, not for the lay positions which comprised the essence of church community life.

Nor did the other outstanding feature of the CSET, a system of badges, prepare boys for spiritual life in the church community. Trail Rangers and Tuxis boys could win up to twenty-four sweater badges by attaining certain standards of expertise in areas such as first aid, public speaking, astronomy, Indian life, and Christian heroes. They could eam badges also by displaying signs of discipline in their choices of entertainment and by developing proper health habits such as swimming or cycling regularly. Frequent attendance at church worship services, helping at home, and doing well at school also merited badges. ${ }^{29}$ While it should not be overlooked that these goals were set with the intent to foster godliness and a community spirit, it is important to recognize that a programme calculated to develop a competitive mindset would have worked against the very spiritual values it set out to instil. As the clergy noticed these contradictions, they looked to the CGIT as a model, altering Statten's CSET to emphasize the relational and spiritual aspects of life.

\section{Canadian Girls in Training}

Much as Statten and the CSET committee had attempted to develop a "muscular Christianity" which would appeal to boys, the women who envisioned the CGIT based their programme on what they perceived to be the naturally feminine instincts of girls. Winnifred Thomas, Olive Zeigler, and Una Saunders created the CGIT programme squarely in the "matemal feminist" tradition of their time. ${ }^{30}$ While clergy and other male social gospellers were preoccupied with the "young boy problem," these women insisted that there was an equally significant "young girl problem." The girl problem was different from the boy problem, however. It was not that girls were leaving the church in the same proportions as their brothers; it was more a question of equal time for girls. Insisting that training tomorrow's mothers was as essential for the future of Canadian society as was work with the prospective male leaders, the YWCA experimented with a variety of strategies which included girls' clubs, summer camps, and Girl Guide companies. ${ }^{31}$ Similar to the YMCA's relationship with Scouts, the YWCA's connection with Guides was short-lived. Although the YWCA sponsored a number of Guide companies when Guiding was introduced into Canada in 1910, by 1917 the YWCA workers decided that the Guide programme was too competitive. Nor was Guiding devoted to religious education. ${ }^{32}$ The YWCA was committed to working with the churches, and these women saw a need for church-sponsored girls' work.

Thus by the autumn of 1915, the YWCA established the National Advisory

Committee for Cooperation in Girls' Work paralleling that for boys. ${ }^{33}$ During 
the following two years under the auspices of this committee, Una Saunders, Winnifred Thomas, and Olive Zeigler prepared a new programme for girls aged thirteen to seventeen which they named the Canadian Girls in Training (CGIT). With little guidance available from the existing literature on the religious education of adolescent girls, Saunders, Thomas, and Zeigler pursued a thorough research campaign in which they discemed the needs of Canadian girls through questionnaires and discussions with YWCA leaders, Sunday-school teachers, Girl Guide leaders and high school teachers. ${ }^{34}$ The CGIT programme that emerged from these years of study and debate has been described as the climax of the YWCA's years of experimentation in girls' work. Modelled after the YWCA's girls' clubs and led by a YWCA worker or a Sunday-school teacher, CGIT, like the CSET, was organized under the YWCA's four standards for development of youth. In sharp contrast to the competitive activities encouraged in the CSET, however, these leaders assumed that girls would serve the church and society best if they were encouraged to adopt co-operative activities.

In the first place, the CGIT programme rejected the competitive badge system common in teen clubs of that time. Although competition hardly fit the feminine ideal, at least one girls' group, the Girl Guides, elected to work with badges. ${ }^{35}$ It seems that the initiators of CGIT deliberately chose to emphasize activities that nurtured a co-operative spirit. For instance, Thomas and her committee encouraged their girls to collaborate in planning and implementing homecraft and missionary projects instead of competing with their friends to collect badges. In addition, CGIT girls were invited to help with the younger children's Sunday 'school classes and mid-week programmes as well as the summer vacation schools. ${ }^{36}$

In the second place, the CGrT leaders recognized that girls' parliaments were unrealistic. In an era in which women had only just received the franchise, they saw citizenship as meaning something quite different than it did for boys. Instead of debating and passing bills, the CGIT officials sought to teach girls the meaning of suffrage and the value of their vote. For this purpose, the National Girls' Work Board adopted a study guide prepared by the Local Council of Women in Regina. This material outlined the structure of the Canadian government and the history of the women's suffrage movement, all the while encouraging girls to vote as soon as they were of age. For CGIT girls in the 1920s, citizenship meant learning to exercise the virtues deemed peculiar to women in their mothering and nurturing capacities in the public sphere. For instance, the creators of the CGIT encouraged girls to become aware of reform issues such as temperance, for they believed that much of the legislation for the protection of women and children was the result of women's votes. ${ }^{37}$ It was these activities that fostered community and spiritual values forming the basis of the CGIT's success as a church group.

In 1921, the same year that the YMCA turned the CSET over to the churches, the CGIT also became a church-sponsored programme, the National Advisory Committee for Cooperation in Girls' Work serving the churches along with the National Advisory Committee for Cooperation in Boys' Work under the auspices 
of the RECC ${ }^{38}$ The RECC's decision to adopt the YWCA programme meant that women had new opportunities to promote CGIT in the churches. Indeed the clergy were dismayed to find the girls' programme to be more successful than the Trail Rangers and Tuxis Boys.

Much of the women's success appears to have been the result of their knowledge of new educational methods. Indeed there was no parallel in the CSET to the CGIT's exciting Bible studies which fostered discussion and intellectual inquiry. The CGIT officials derived their techniques from their experience with the "new evangelism" 39 and the principles of "progressive education" or the "new education," as it was called in Canada. ${ }^{40}$ The male religious educators also advocated new educational methods, ${ }^{41}$ but it appears that it was the CGIT leaders who introduced the new approach.

In contrast to the older established clergy who served as religious educators, the CGIT officials were younger and were recent university graduates. ${ }^{42}$ Schooled in the student YWCA and the Student Christian Movement, the women were among the generation of students for whom wartime conditions had fostered a new sense of independence and a greater social vision. ${ }^{43}$ These young people believed it was their task to reconstruct society, or to build the City of God. While these goals were characteristic of deep personal faith, university students of the twenties had become disillusioned with institutional religion for its involvement with the war effort and its slowness to accept the findings of modern science. Thus they thrived on studies of the historical Jesus led by H. B. Sharman, a key figure in the SCM, whose thinking bore the mark of liberal theology and modern Biblical criticism. ${ }^{44}$

The CGIT officials then effectively combined what they had learned from the SCM Bible studies with elements of progressive education, for the women had a further edge on the male leaders. In the first place, numerous young men had been lost in the war, and in the second place, young women were more inclined than their male peers to attend the normal schools, where teachers espoused the progressive theories of John Dewey and his disciples. Thus there was a pool of women teachers. For many women, paid teaching in the elementary schools only provided an interlude in lifelong commitment as a volunteer in the local Sunday school. Time and again religious educators praised young school teachers for their willing leadership in the Sunday schools and mid-week clubs: ${ }^{45}$

It would be difficult to overestimate the importance of the work of a girl in a lonely country school. Here she is teacher, but in many instances, much more than a teacher, for she is a sort of general servant of the community, giving leadership in every good work. She is found teaching Sunday-school, where no one had thought of it. ${ }^{46}$

When marriage and motherhood terminated these young teachers' formal careers, many devoted their energies to the church and community. 
In marked contrast to the abundance of women available to teach Sundayschool classes, religious educators were frustrated by the chronic shortage of male teachers. For instance Oliver Jackson, the Superintendent of Missions and Religious Education in Newfoundland, was convinced that the low interest in Trail Rangers was directly related to "the lack of the right type of leader, apart from the minister." 47 Another official, David Forsyth, believed that "the discovery of leadership is the greatest need that exists in our United Church Boys' Work., 48

Many men probably had their hands full earning a living to suppont their families, but among those that did find time to volunteer in the churches, few had the training and expertise to apply the concepts of Christian nurture to their work with boys, for few men had trained as teachers. In contrast, the CGIT officials and local leaders found the liberal churches to offer more opportunities than even the public schools to practice the "new education" techniques which they had learned in the normal schools, for Canadian schools were stow to adopt the new ways. $^{49}$

Armed with the new educational philosophy and Sharman's methods, women such as Olive Zeigler and Winnifred Thomas had created a programme designed to "take the trouble to think with the present generation of students in terms which they can understand, not in a dogmatic or theological way, but in terms of a strong, Christian Way of Life under the leadership of Christ." seriously did they take their mandate that CGIT leaders wrote many of their own materials. For example Thomas' Bible sudy, The Kingdom of God, was used over several summers at CGIT camps and by many local groups. This study was based entirely on the synoptic gospels and used the Sharman method "to make real to girls 'the Jesus of history...to lead them to see clearly what he meant when he spoke of the Kingdom of God' and to inspire them 'to commit unreservedly to the extending of His Kingdom in the world'." Thomas advised leaders to use "'research and discussion' and to encourage 'girls to do their own thinking. It is irreverent to approach the study of the Bible with a lazy mind", she wrote."

The CGIT programme made a great impact on the girls who were fortunate enough to come under its influence. Take for instance Doris McCarthy, a Canadian artist. In writing her memoirs, she devoted an entire chapter to what she called "the bliss of growth" that she had experienced under the influence of the CGIT in the 1920s. In recounting her experience with CGIT Bible studies, she recalled:

For the first time in my life I understood how the disciples and the early church had struggled to find words to say what they had come to feel about Jesus. After meeting Jesus the man $Y$ could rearn to the language of the church and find it full of meaning. Even the theological words of the creed made sense, especially with some judicious personal reinterpretation. 
She continued, "this was the new light that I wanted" for other younger girls. Bored by the more traditional Sunday-school experience, McCarthy volunteered to teach, initiating a new CGIT group for younger teens at Toronto's St. Aiden's United Church. ${ }^{52}$ With results like this, it is small wonder the male officials continually held up the ginls' movement as a model and aimed for comparable results in their boys' clubs.

\section{The Feminization of the Trail Rangers and Twxis Boys}

Of course in 1912 when Statten and his colleagues prepared the CSET, they had had no exposure to the Sharman method. Moreover, as was already mentioned, far fewer men than women had the advantage of normal-school training. This may explain the cautious manner in which boys' workers adapted their religious and moral instruction to the new understandings of education. As they gradually gave up mass meetings to attempt group Bible studies, these leaders found themselves inadequately prepared to conduct such studies. ${ }^{53}$ Nor did they have materials from which to work. The second problem was solved easily enough. It was fairly straightforward to bonrow from the materials already published by the girls' workers. ${ }^{54}$ The real difficulty lay in finding leaders capable of leading good Bible discussions.

The boys' club in Midland, Ontario is a case in point. Evidently the leaders were poorly equipped to attempt serious study and group activities. Instead, they organized a hockey team and a yearly hobby show. An annual father and son banquet was their only concession to the spiritual and relational end of church life. Such banquets were encouraged by the International Council of Religious Education during Father and Son Week in the attempt to redeem the fragmented father and son relationships of the industrial era. It is significant, however, that in Midland this event was entirely dependent on the women's auxiliary. The ladies prepared and served the meals, but when their group took on a catering contract for another organization, there were no more father and son banquets in Midland. ${ }^{55}$

In the absence of male leaders, women often taught boys, mentoring them in the decidedly more feminine aspects of church life in the process. For instance, Mrs. George Weir, the pastor's wife at Saint Andrew's United Church in Ripley, Ontario, taught a class of young men. In contrast to the boys in Midland whose father and son banquet was terminated when there were no longer women to serve them, Mrs. Weir's boys did the serving at the annual grandmother, mother, and daughter banquet. $^{56}$

Wrestling with the problem of finding suitable men to lead the boys' clubs, male administrators recommended merging boys' and girls' groups, or at least bringing them together with the young people's meetings on the same evening. ${ }^{57}$ These officials hoped that co-ordinated activities would create a larger momen- 
tum than a small group could by itself. ${ }^{58}$ The girls' leaders conceded that it was important for boys and girls to interact socially and were willing even to lend their materials to the flagging boys' movement. They balked, however, at suggestions which hinted at amalgamation of the veen groups. In 1929, Mary Allison cautioned officials against moving too quickly on joint activities:

Our concem regarding the need of developing joint activities and the correlating of Boys' and Girls' and Young People's Work seems so far to be too much based on "generalized" feelings and marked tendencies, together with "hunches" as to the causes underiying. 59

That same year, Bona Mills appeared relieved that while many "seemed to consider the separateness of the teen-age movemenis during the past years a distinct weakness, there were none who felt complete merging would be advisable." ${ }^{60}$ In her study of the CGIT movement, Gabrielle Blais hypothesized that this may have been for two reasons. First, the CGIT leaders were aware that girls were more mature than boys of their own age. Second, young women leaders may have been ambivalent about their own relationship with men. ${ }^{61}$ It seems more likely, however, that the CGrT leaders refused to give up the independence that they and their girls experienced in their own mid-week mestings.

The teen programmes remained separate, but by 1929 a common approach had evolved which revamped the youth agenda to fit the feminine model, focusing on co-operation and relationships. ${ }^{62}$ In the hopes of integrating the spiritual with other aspects of the teen agenda, the revised programme deliberately directed attention away from the individual to relationships with the home, school, church, and community. It was hoped that this altered focus would result in a greater loyalty to the church. ${ }^{63}$

Club leaders were urged again and again to emphasize the connection of their groups with the church school. Volumes of correspondence went out from the head office, encouraging local leaders to emphasize Bible Study, decisions for Christ, church membership, temperance education, and missionary promotion. ${ }^{64}$ Officials believed that under the new system, teen groups were "more accessible to the minister and his associates in Christian leadership than before." 65 Such studies as Climbing Life's Highway by Melville C. Wright aimed to capitalize on the religious awakening that occurred during the teen years. ${ }^{66}$ Nurturing boys into the faith was far from natural in a "feminized" church, however. By the mid-1920s, a revised Tuxis and Trail Rangers programme emphasized the relational, forfeiting the more individualistic ideals of the four-fold plan. No longer were badges or Boys' Parliaments emphasized. In marked contrast to the aggressive nature of team sports, the new programme encouraged boys to co-operate with one another in group, relay, and challenge games such as stride ball, weavers' relay, club snatch, and rooster fight. This would permit the less skilful boys to participate on a more equal basis than team games such as hockey 
and baseball permitted. The new approach stressed that competition failed to foster the fellowship essential to a good devotional attitude. ${ }^{6}$

Further, the new programme distinguished between argument and discussion, instructing mentors on the purpose of such exchanges:

The lecture method may be easier for the mentor but a lecture represents one way traffic of thought....Every mentor should strive to give part of the study period to discussion. Argument is not discussion. To crush or defeat another's theories and opinion is to miss an opportunity of sharing intellectually. Discussion should become a pooling of ideas and, as such, is highly desirable. ${ }^{68}$

It is difficult to determine the impact of such advice on leaders of boys' groups. It is evident, however, that the national leadership adopted the feminine values of co-operation and relationships which had been fostered in the CGIT movement right from its inception.

While it is difficult to know how many of the Trail Rangers' and Tuxis Boys' leaders attempted to implement these co-operative principles, one might hypothesize that this "feminization" of the church teen boys' clubs was at least partially responsible for the ongoing interest of many boys and leaders in Scouts. ${ }^{69}$ Veronica Strong-Boag has suggested that while girls of that day, much like the giris of today, enjoyed peaceful and co-operative projects, boys were intrigued by more competitive activities. ${ }^{70}$ Norman Coll's observation that many United Church boys and leaders in Ottawa and Montreal had joined the Boy Scout movement, then, is hardly surprising. The situation in that conference was, at least in part, a result of the Board of Religious Education's decision to alter the boys' programmes. Many United Church boys and men shunned what must have seemed to them an "unmanly" emphasis on co-operation, in favour of the more competitive Scout programme. Timothy Eaton Memorial United Church in Toronto is a case in point. That institution's historian notes that while the CSET programmes were started there in the 1920 s, by the end of that decade Boy Scouts and Cubs had replaced them. ${ }^{71}$ Other churches like Century-Queen Square in Saint John, New Brunswick, ran both programmes simultaneously during those years. $^{72}$

By 1933 officials recognized that their programme was in danger, for United Church boys and men preferred Scouts to Trail Rangers. A committee designed to analyse the problem affirmed United Church support in theory for any "Christ-centred" boys' programme which aimed "to bring the boy into natural and full Christian fellowship and Church Membership." Since the Boy Scout movement made no claim to be a church-centred programme, however, the Board of Religious Education declared that in practice, it would continue to give official recognition only to the Trail Ranger and Tuxis programmes.

While many boys were unimpressed by their new co-operative church programme, the CGIT continued to appeal to girls. It is important to emphasize, 
however, that teen-age girls hardly found egalitarian opportunities in the "feminized" church of the interwar decades. The prolonged struggle for ordination continually reminded CGIT leaders of the limited opportunities for girls in the institutional church. ${ }^{74}$ The 1932 Leader's Book acknowledged the situation: "In the case of the worship of the Sunday session," it read, girls were offered "comparatively little opportunity of contributing." $" 75$ Nevertheless, young women were fortunate to have more opportunities in their CGIT groups than they had in coeducational settings. In CGIT, girls learned to participate in discussions, conduct business meetings, keep minutes and accounts, and prepare and lead worship services. ${ }^{76}$ By circumventing the male ministers and Sunday-school superintendents, the CGIT leaders themselves could maintain control of their groups and teach their girls important life-skills. Thus while CGIT officials were willing to share their materials and expertise with boys' leaders, in the tradition of other women's organizations, they held tenaciously to their autonomy and independence. As Strong-Boag has pointed out, "in some ways,...CGIT represented only a more formal opportunity to participate in a long-existing female culture and cultivate female friendships." ${ }^{77}$

\section{Conclusion}

This study of the CSET and the CGIT programmes in the 1920s and 1930s suggests that the relational ideology and co-operative methods which suited girls reflected also the goals of the Methodist and Presbyterian religious educators. This conclusion substantiates the hypothesis that liberal Protestant churches had become "feminized" institutions. For instance in 1938, the executive of the Young People's Union noted with alarm:

Grave concern is experienced in many Churches because, in most of the Churches' activities, the men of the congregation are conspicuous by their absence....The men are found usually in Public Worship and on Church Boards. A few teach in the Sunday School, or sing in the Choir. Occasionally they join in a mixed or Men's Bible Class. In most Churches, however, practically all the Service work is done by the Women's Association, the Missionary Education by the Women's Missionary Society, the Mission Circle or Auxiliary, and the Adult Religious Education by Women's Bible Classes.

During these decades Canadian Methodist and Presbyterian clergymen, worried about the exodus of boys from their churches, experimented with educational methods which they hoped would interest boys in church life. By 1912, church officials had joined forces with the YMCA, supporting the new CSET programme. Excited about Taylor Statten's "muscular" version of Chris- 
tianity, clergymen pictured male mentors encouraging boys to live active Christian lives through the competitive programme of badges and Boys' Parliaments. The boys' programme worked under a handicap, however, for there was a dearth of qualified men interested in teaching boys.

The girls' programme, on the other hand, had the advantage of large numbers of women in the churches, many of whom had been previously trained as elementary school teachers and who were eager to lead local groups of girls. Thus when the YWCA followed the YMCA's precedent, creating the CGIT as a programme to parallel the CSET, they found many positive responses in the churches. The CGIT was based on the premise that teaching girls the art of Christian womanhood was equally significant to training young men. The YWCA women, however, deliberately rejected such competitive aspects of the boys' programme as badges. Instead they concentrated on teaching girls relational and co-operative skills. As recent college graduates, the women who created the CGIT programme used the knowledge they had gained from SCM Bible studies and progressive educational methods to train girls to enjoy critical discussion and dialogue.

Although the Trail Rangers and Tuxis boys' clubs initially outnumbered CGIT groups, this trend soon reversed itself. While grappling with the shortcomings of their programme, clergymen observed the success of the CGIT and began to look to the girls' programme as a model. By 1927, religious educators altered the old approach of the CSET, softening its more competitive aspects to take on the relational and co-operative characteristics of the CGIT. While the new boys' programme fit better into church life, its appeal to boys and their leaders was limited. Boys and men preferred competitive activities such as those promoted by the Scouts. Further, few laymen were qualified to teach with modern educational methods. Thus in the end, CGIT, offering girls opportunities long held by women's groups to nurture relationships in the church, provided a starting point for a variety of other avenues of service, while boys continued to drift away from the churches for lack of a programme that spoke to their needs.

\section{NOTES}

* An earlier version of this paper was presented at the Canadian History of Education Association meeting in October 1990.

1. United Church of Canada Archives, Victoria University [hereafter UCA], United Church of Canada [UCC], Board of Religious Education [BRE], Minutes, Apr. 1929, 69.

2. The Presbyterians took the lead in encouraging their congregations to become aware of the importance of religious training for teenage girls, selecting May Gemmell, a Queen's University graduate, as its first girls' work secretary in 1918, immediately on the heels of the appointment of that denomination's first field secretary. By 1919, the Methodists followed suit, also hiring a girls' secretary. UCA, Presbyterian Church of Canada, General Assembly (1918), 221. 
3. Ann Douglas, The Feminization of American Culture, 2nd ed. (New York: Doubleday, 1988), 13, 17-19.

4. This study emerges from the larger context of my doctoral thesis in which I analysed youth groups of all ages. I found that the ratio of girls to boys remained constant at about two-thirds girls and one-third boys. For instance, in 1920, among Methodist pre-teens there were 9,000 boys compared to some 17,000 girls. The ratio of boys to girls was similar for the post-high school group with some 19,000 boys compared to some 36,000 girls. "Church Hierarchy and Christian Nurture: The Significance of Gender in Religious Education in the Methodist, Presbyterian and United Churches of Canada, 1919-1939" (University of Waterloo, 1990), 195, n.2.

5 Several scholars have analysed these club movements as part of the carly twentiethcentury reformers' efforts to mould the nation's youth into good Christim citizens. Margaret Prang and Gabrielle Blais have provided interesting and thought-provoking studies of the Canadian Girls in Training Movement. See Prang, "The Girl God Would Have Me Be': The Canadian Girls in Training 1915-1939," Canadian Historical Review 66, 2 (June 1985): 154-84; Gabrielle Blais, "The Complete Feminine Personality: Female Adolescence in the Canadian Girls in Training (CGIT) 1915 55" (M.A., University of Ottawa, 1986). Diana Pedersen has provided further insights into the development of the CGIT in "Young Women's Christian Association of Canadia, 1870-1920: A Movement to Meet a Spiritual, Civic and National Need" (Ph.D. diss., Carleton University, 1987). The parallel programme for boys, the Canadian Standard Efficiency Training (CSET), has aroused less scholarly interest thus far, but David Mcleod contributed some valuable insights into that movement in "A Live Vaccine: The YMCA and Male Adolescence in the United States and Canada, 1870-1920," Histoire sociale/Social History 11, 2 (May 1978): 5-25. Patricia Dirks has set the programme in the context of Methodist history: see "'Getting a Grip on Harry': Canada's Methodists Respond to the 'Big Boy' Problem, 1900-1925," Canadian Methodist Historical Saciety Papers (1989): 67-82. Leila Mitchell McKee has attempted the only study thus far in which both the boys' and girls' programmes have been analysed as parallel movements, but she made few efforts to understand the differences which gender made on the two programmes. See "Voluntary Youth Organizations in Toronto, 1880-1930" (Ph.D. diss., York University, 1982). Even though these programmes had become primarily churchrun organizations by 1919 , only Dirks analysed youth work from the perspective of church history.

6. In 1921, the National Boys' Work Board estimated that there were approximately 1,800 boys groups across Canada although they only had 1,361 groups on record in the national office; in contrast, the National Girls' Work Board had about 1,700 groups on record. By 1929, the UCC Yearboak recorded that there were close to 2,200 girls' clubs, four hundred more than boys. By 1939, the gap had become even wider. There were seven hundred more girls' clubs than there had been a decade earlier, while the boys' organizations had actually dwindled so that there were only about two-thirds as many boys' clubs as there were girls' clubs. UCA, Religious Education Council of Canada (RECC), Minutes (9 Sept. 1921): 13, 15; UCC, Yearbook (1929): 182; (1939): 39.

7. J. H. Riddell noted that this concem first came up in the Methodist church at the General Assembly of 1904. Methadism in the Middle West (Toronto: Ryerson Press, 1946). See W. B. Forbush, "Training the Boy," in The Encyclopedia of Sunday Schools and Religious Education, ed. J. T. McFarland et al. (New York \& London: 
Thomas Nelson \& Sons, 1915), 161, for a list of books which attempted to deal with boys' needs in the early twentieth century. Patricia Dirks has dealt exclusively with the boy problem as well in "Getting a Grip on Harry," and "Finding the "Canadian' Way: Origins of the Religious Education Council of Canada," Studies in Religion 16, 3 (Summer 1987): 303-16.

8. David Mcleod based this hypothesis on the "feminization" theory developed by Douglas, in Feminization of American Culture: "A Live Vaccine," 6, n.3, 9-11, 13.

9. Murray G. Ross, The Y.M.C.A. in Canada: The Chronicle of A Century (Toronto: Ryerson Press, 1951): 194-95.

10. Douglas' Feminization of American Culture was preceded by Barbara Welter's "The Feminization of American Religion: 1800-1860," in Clio's Consciousness Raised: New Perspectives an the History of Women, ed. Mary Hartman and Lois W. Banner (New York: Harper \& Row, 1974): 135-57.

11. Samuel D. Clark, Church and Sect in Canada (Toronto: University of Toronto Press, 1948): 261.

12. Horace Bushnell was the father of the theology of Christian murture. See Christian Nurture, reprinted from the 1861 edition (Grand Rapids: Baker Book House, 1979). For further discussion on the theology of Christian nurture see Neil Semple, "The Nurture and Admonition of the Lord': Nineteenth-Century Canadian Methodism's Response to "Childhood"," Social History/Histoire sociale 14, 27 (May 1981): 157-76. While there are no similar studies of the development of Presbyterian thought on this issue, John McNeill pointed out that John Thompson, the first Presbyterian Sabbath school convener, held to Bushnell's view of Christian nurture. See The Presbyterian Church in Canada, 1875-1925 (Toronto: General Board, Presbyterian Church in Cansda, 1925): 158-59. See also Douglas, Feminization of American Culture, 121-64; Arne M. Boylan, Sunday School: The Formation of an American Institution: 1790-1880 (New Haven and London: Yale University Press, 1988): 133-65.

13. Douglas, Feminization of American Culture, 112.

14. I deal more extensively with this concept in chap. 6 of my Ph.D. dissertation.

15. E. Anthony Rotundo, "Body and Soul: Changing Ideals of American Middle-Class Manhood, 1770-1920,"Journal of Social History 16,4 (1983): 30. See also David Mcleod, "A Live Vaccine," and "Act Your Age: Boyhood, Adolescence, and the Rise of the Boy Scouts of America," Journal of Social History 16, 2 (Winter, 1982): 3-20.

16. Rotundo, "Body and Soul," 29-32.

17. Mcleod, "A Live Vaccine," 10-11; J.H. Keth, Rites of Passage: Adolescence in America, 1790 to the Present (New York: Basic Books, 1977): 173.

18. Ross, The Y.M.C.A. in Canada, 33, 323; "The Cansdian Boys' Work Plan," Religious Education 14, 2 (Apr. 1919): 107.

19. Mcleod, "A Live Vsccine," 15-16; Dirks, "Finding the 'Canadian' Way," 309-10.

20. By 1920, this committee became known as the National Boys' Work Board [NBWB]. C.A.M. Edwards, Taylor Statten (Toronto: Ryerson Press, 1960): 47-48; UCA, The Boys' Own Boak (Tomnto: National Boys' Work Board of the Religious Education Council of Canada, 1929): 9-10.

21. Mcleod, "A Live Vaccine," 20; John T. McNeill. The Presbyterian Church in Canada, 1875-1925 (Toronto: Presbyterian Church in Canada, 1925): 181-82.

22. Mcleod, "A Live Vaccine," 22; Ross, The Y.M. C.A. in Canada, 354.

23. Dirks describes the development of the RECC in "Finding the "Canadian' Way." 
24. Mcleod, “A Live Vaccine," 22; Ross, The YM.CA. in Canada, 203-5.

25. UCA, The Canadian Standard Efficiency Training for Trail Rangers and Tuxis Boys (Toronto: Committee on Canadian Standard Efficiency Training, 1918): 3.

26. The article by J. M. Artman was originally published in Religious Education and reprinted in The Canadian Mentor (Jan. 1925): 1,7.

27. The New Outloak (23 Feb. 1927): 15.

28. The Canadian Mentor (Jan. 1925): 1; see also The Canadian Standard Efficiency Training, 9 and The Boys' Own Book (Toronto: National Boys' Work Board of the RECC, 1929): 30-31.

29. The Canadian Standard Efficiency Training, 405-421.

30. Linda Kealey defined "maternal feminism" as "the conviction that women's special role as mother gives her the duty and the right to participate in the public sphere." A Not Unreasonable Claim: Women and Reform in Canada, 1880s-1920s (Toronto: Women's Educational Press, 1979): 7.

31. Pedersen, "Young Women's Christian Association," 2, 468.

32. Pedersen, "Young Women's Christian Association," 388; Prang, "The Girl God Would Have Me Be," 159.

33. Early in 1920 this committee became known as the National Girls' Work Board. Prang, "The Girl God Would Have Me Be," 158, n.13.

34. Prang, "The Girl God Would Have Me Be," 158-60; Pedersen, "Young Women's Christian Association," 391, 400-1. See also Gertrude E. Griffith, "The Girl," Encyclopedia of Sunday Schools, I; 450. In Griffith's words, "the problem of the boy has demanded...attention....As a consequence of... wide-spread interest, a wealth of material on...this subject has been produced....That such material concerning the girl in her teens is not equally available, has been the cause of real concem among persons actively interested in...the adolescent girl."

35. McKee mistakenly suggested that CGIT also used badges. "Voluntary Youth Associations," 404. See also Helen Lenskyj, "Femininity First: Sport and Physical Education for Ontario Girls, 1890-1930," Canadian Journal of History of Sport 13, 2 (1982): 4-17.

36. UCA, UCC, BCE Collection, The Leaders' Book.

37. Prang, "The Girl God Would Have Me Be," 172-73.

38. Pedersen, "Young Women's Christian Association," 401.

39. Richard Allen, The Social Passion: Religious and Social Reform in Canada 1914-28 (Toronto: University of Toronto Press, 1971): 224-25.

40. Prang, "The Girl God Would Have Me Be," 163.

41. UCA, PCC, GA (1923): 269.

42. Prang, "The Girl God Would Have Me Be," $165,170$.

43. Elizabeth Anderson showed that women participated almost equally with men at all levels of activity in the SCM in the twenties. UCA, "Women and the Student Christian Movement of Canada, 1921-1949" (Unpublished paper, 1980): 12.

44. Prang, "The Girl God Would Have Me Be," 165; Donald L. Kirkey, "Building the City of God': The Founding of the Student Christian Movement of Canada" (M.A., McMaster University, 1983): 3, 5, 51-53, 88-89, 102-3, 153 54.

45. For instance, Oliver Jackson praised public school teachers in Newfoundland for their contribution to religious education. UCA, UCC, BCE, Minutes (Apr. 1937): 77.78. See also Teacher's Monthly (Nov. 1924): 644.

46. The New Outlook (2 Dec. 1925): 25 .

47. UCA, UCC, BCE, Minutes (Apr. 1937): 77-78. 
48. UCA, UCC, BCE, Minutes (Apr. 1937): 72.

49. Prang, "The Girl God Would Have Me Be," 163-64; see also Robert Stamp, The Schools of Ontario, 1876-1976 (Toronto: University of Toronto, 1982): 51-53; 164.67.

50. UCA, Methodist Church of Canada [MCC], Board of Sunday Schools and Young People's Societies [BSSYP], Minutes (1920): 71.

51. UCA, Winnifred Thomas, The Kingdom of God (Toronto: National Girls' Work Board, c. 1926); Prang, "The Girl God Would Have Me Be," 166-67.

52. Doris McCarthy, A Fool in Paradise: An Artist's Early Life (Toronto: MacFarlane Walter \& Ross, 1990).

53. Mcleod, "A Live Vaccine," 16.

54. The Board of Religious Education recommended a number of sources from the NGWB to boys' workers: The Use of the Bible in Worship, The Use of Poetry and Prayer in Worship, The Use of Stories in Worship, From Dawn to Dawn, Heralds of the Dawn, A Treasure Book of Books, A Treasure Book of Discussions. The NBWB adapted several other NGWB publications for boys' use: $A$ Girls' Practice of the Presence of Gad, The Kingdom of Love, The Message of Jesus for the Life of Today. UCA, UCC, BCE Collection, Boys' Work, Box 3, Files 9-10, "List of Supplies for Trail Rangers and Tuxis Groups," 1932-33, and "The Programmeme of Boys' Work in the United Church of Canada."

55. UCA, UCC, BCE Collection, Boys' Work, Box 3, File 8, "Boys' Work in Midland"; Box 10, File 47, "Father and Son Week" (Nov. 1931).

56. St. Andrew's United Church, Ripley, Ontario, 1886-1986 (Mildmay, Ontario: The Town \& Country Crier, 1986): 35.

57. UCA, UCC, BRE, Minutes (31 Aug. 1926): 10.

58. UCA, The Torch (Nov.-Dec. 1929): 35-36; BCE Collection, Boys' Work, Box 3 , File 9.10, Mentoring: Programme Suggestions for Trail Ranger and Tuxis Leaders, 30.32 .

59. UCA, UCC, BRE, Minutes (Apr. 1929): 54.

60. UCA, UCC, BRE, Minutes (Apr. 1929): 55.

61. Blais, "The Complete Feminine Personality," 65-66.

62. Carol Gilligan's hypothesis helps explain the different emphases in the boys' and girls' clubs of the twenties and thirties. Gilligan argues that for girls, relationships are primary whereas boys develop a separate and independent identity at an early age. See In a Different Voice: Psychological Theory and Women's Development (Cambridge, Mass.: Harvard University Press, 1982): 160 61.

63. UCA, UCC, BRE, Minutes (31 Aug. 1926): 11. By 1929, a new book for leaders replaced the old Canadian Standard Efficiency Training manual. Creative Leadership for Mentors and Workers with Boys, for Leaders in Boys' Work, Parents, Teachers, Ministers and All Interested in the Development of Canadian Boyhood (Toronto: National Boys' Work Board of the RECC, 1929). By 1932, the National Girls' Work Board published a new manual for girls which also outlined these ideas, The Leader's Book (Toronto: National Girls' Work Board of the RECC, 1932).

64. UCA, UCC, BRE, Minutes (5 May 1927): 105-6; UCC, Yearbook (1927): 132.

65. The Canadian Mentor (Apr. 1931): 5.

66. C. Melville Wright, Climbing Life's Highway: A Study of What Church Membership Means (Toronto: United Church Publishing House, 1926); UCC, Yearbook (1928): 340-41; The Torch (Jan.-May 1930): 50-51; The Canadian Mentor (Apr. 1931): 5. 
67. UCA, UCC, BRE, Minutes (18 Mar. 1926): 22; BCE Collection, Boys' Work, Box 3. File 9-10, Mentoring, 8, 15, 22 and "The Trail Rangers and Tuxis Boys" Programmes." See also McKee, "Voluntary Youth Associations," 409-10.

68. UCA, UCC, BCE Collection, Mentoring, 28.

69. Undoubtedly many local church groups, like the club in Midland, continued to emphasize the physical. For instance, the situation of a boys' church club of the 1950 s that was more physically rough and competitive than the local Scouts group has been brought to my attention.

70. Veronica Strong-Boag, The New Day Recalled: Lives of Girls and Women in English Canada, 1919-1939 (Mississauga: Copp Clark Pitman Ltd., 1988): 30.

71. Shirley Ayer, A Great Church in Action: A History of Timothy Eaton Memorial Church, Toronto, Canada, 1909-1977 (Whitby: Plum Hollow Books, 1978).

72. Milestones in Methodism: A History of Centenary-Queen Square United Church of Canada, Saint John, New Brunswick, 1790-1966 (Saint John, New Brunswick: Lingley Printing Co. Ltd., 1967): 160.

73. UCA, UCC, BCE Collection, Boys' Work, Box 11, File 48, "Report of a Committee to Consider the Attitude of this Board to the Boy Scout Movement," 6 Apr. 1933.

74. After years of struggle, women in the United Church of Canada finally achieved the privilege of ordination in 1936. For a description of those years and the issues involved see Nancy Hall, "The Professionalisation of Women Workers in the Methodist, Presbyterian, and United Churches of Canada," in First Days, Fighting Days: Women in Manitoba History, ed. Mary Kinnear (Regina: University of Regina Press, 1987): 120-33; Mary Hallet, "Nellie McClung and the Fight for the Ordination of Women in the United Church of Canada," Atlantis 4 (Spring 1979): 2-16; see also chap. 3 of my Ph.D. dissertation on this subject.

75. Leader's Book, 11.

76. Prang, "The Girl God Would Have Me Be," 170-71.

77. Strong-Boag, The New Day Recalled, 29.

78. UCA, UCC, BCE Collection, National Young People's Union, Second National Congress, 1938. 